Neuroendocrinology 1970;6:I-VIII

\title{
Contents, Vol. 6, 1970
}

\author{
International Journal for Basic and Clinical Studies on \\ Neuroendocrine Relationships
}

Managing Editor: E.

Bajusz, Boston, Mass.

Editors: D. DE WIED, Utrecht,

K. KNIGGE, Rochester, N.Y.

Editorial Board:

I. ASSENMACHER, Montpellier

C. BEYER, Mexico

A. BRodish, Cincinnati, Ohio

V. CRITCHLOW, Houston, Tex.

S.A. D’ANGELO, Philadelphia, Pa.

P.M. DANIEL, London

E. ENDRÖCZI, Pécs

W. ETKIN, Bronx, N.Y.

J.W. EVERETT, Durham, N.C

B. FLeRKó, Pécs

W.H. FLORSHEIM, Long Beach, Cal.

W.F. GANONG, San Francisco, Cal.

R. GORSKI, Los Angeles, Cal.

M.A. GREER, Portland, Ore.

C.E. Grosvenor, Memphis, Tenn.

R.J. WURTMAN, 
R. Guillemin, Houston, Tex.

J.R. HoDGES, London

T. HÖKFELT, Stockholm

J.W. KENDALL, Portland, Ore.

H. KOBAYASHI, Tokyo

T. KOBAYASHI, Tokyo

L. LEVI, Stockholm

R. LISK, Princeton, N.J.

L. MARTINI, Milan

S.M. MCCAnN, Dallas, Tex.

J. MEITES, East Lansing, Mich.

H. PURVES, Dunedin, N.Z.

J. REITER, Rochester, N.Y.

V. SCHREIBER, Prague

S. TALEISNIK, Cordoba, Argentina

Cambridge, Mass. 
Vol. 6

S. KARGER BASEL MÜNCHEN NEW YORK 
S. Karger AG, Arnold-Böcklin-Strasse 25, 4000 Basel 11 (Switzerland)

All rights, including that of translation into other languages, reserved.

Photomechanic reproduction (photocopy, microcopy) of this volume or parts thereof without special permission of the publishers is prohibited.

(C)

Copyright 1970 by S. Karger AG, Basel

Printed in Switzerland by Buchdruckerei Kohlhepp AG, Neuallschwil

Blocks: Steiner \& Co., Basel 


\section{Index}

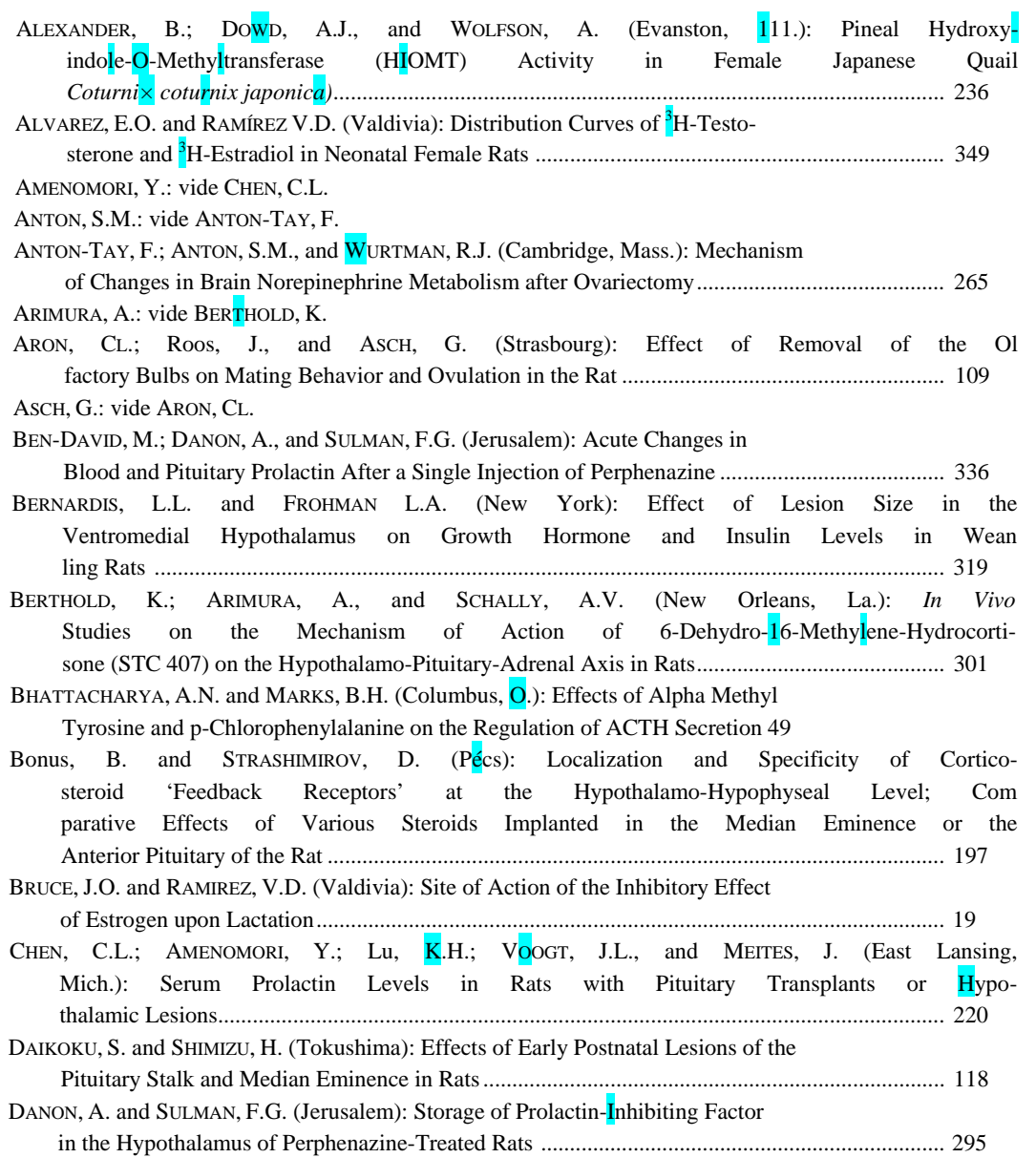


DANON, A.: vide BEN-DAVID, M

DEBELJUK, L.: vide LAWZEWITSCH, IRENE VON

DOWD, A.J.: vide ALEXANDER, B.

EGDAHL, R.H.: vide SALCMAN, M.

Eleftheriou, B.E. (Bar Harbor, Me.): Effects of Amygdaloid Lesions on Hypo thalamic Norepinephrine Response to Increased Ambient Temperature 175

ENDRÖCZI, E.: vide FENDLER, K.

EveretT, J.W.; Holsinger, J.W.; ZeILMAKER, G.H.; REDMOND, W.C., and QuINN, D.L. (Durham, N.C.): Strain Differences for Preoptic Stimulation of Ovulation in Cyclic Spontaneously Persistent-Estrous, and Androgen-Sterilized Rats ... 98

Fendler, K.; Vermes, I.; StARK, A.; ENDrÖczi, E., and LissáK, K. (Pécs): Effect of Cervical Sympathectomy on the Development of 'Miniature Neurohypophysis' and on the Neurosecretory Nuclei of the Hypothalamus after Transection of the Pituitary Stalk.... 194

FogLIA, V.G.: vide MOGUILEVSKY, J.A.

FONTHAM, E.H.: vide MACLEOD, R.M.

FRANCE, E.S. (Philadelphia, Pa.): Reversal by Pargyline of Reserpine Block of Induced Ovulation - Direct Ovarian Effects....

FROHMAN, L.A.: vide BERNARDIS, L.L.

GALE, C.C.: vide TOIVOLA, P.

GAZIRI, L.C.J.: vide LADOSKY, W.

GEORGE, R.: vide KOKKA, N.

GEORGE, R,: vide LOMAX, $\mathrm{P}$.

GUZEK, J.W.: vide TRACZYK, W.Z.

HALÁSZ, B.: vide KÖVES, K.

HernandeZ, J. and IllnerovÁ, H. (Prague): 5-Hydroxytryptophan Decarboxylase Activity in the Rat Pineal Gland During the First 20 Days of Postnatal Life: Effect of Light ...... 343

Hirono, M.; IgARASHI, M., and MATSumOto, S. (Maebashi): Short- and AutoFeedback Control of Pituitary FSH Secretion..... 274

HOLSINGER, J.W.: vide EVERETT, J.W.

IBUKI, T.: vide KAWAKAMI, $M$.

IGARASHI, M.: vide HIRONO, M.

ILLNEROVÁ, H.: vide HERNANDEZ, J.

JONGKIND, J.F.: vide SWAAB, D.F.

KALRA, S.P.: VElASCO, M.E., and SAWYER, C.H. (Los Angeles, Cal.): Influences of Hypothalamic Deafferentation on Pituitary FSH Release and Estrogen Feed back in Immature Female Parabiotic Rats ................................................................... 228

KAWAKAMI, M.;TERASAWA, E., and IBUKI, T. (Yokohama): Changes in Multiple Unit Activity of the Brain During the Estrous Cycle ............................................................. 30

KLEIN, D.C.: vide ROWE, J.W.

KoKKA, N. and GeORGE, R. (LOS Angeles, Cal.): Effect of Hypothalamic Stimu lation on Blood Glucose in the Rabbit .................................................................... 1

KOKKA, N.: vide LOMAX, P.

Kostowski, W.; Rewerski, W., and PIECHOCKI, T. (Warsaw): Effects of Some Steroids on Aggressive Behaviour in Mice and Rats

Köves, K. and HaLÁsz, B. (Pécs): Location of the Neural Structures Triggering Ovulation in the Rat

LADOSKY, W. and GAZIRI, L.C.J. (Curitiba): Brain Serotonin and Sexual Differ entiation of the Nervous System

LAWZEWITSCH, IRENE VON; DEBELJUK, L., and PUIG, R. (Buenos Aires): In Vivo Effect of Beef Hypothalamic Extracts on the Cells of Rat Adenohypophysis 65 
LEHMEYER, J.E.: vide MACLEOD, R.M.

LEŠNIK, H.: vide TRACZYK, W.Z.

LIBERTUN, C: vide MOGUILEVSKY, J.A.

LISSÁK, K.: vide FENDLER, K.

LOMAX, P.; KOKKA, N., and GeORGE, R. (LOS Angeles, Cal.): Thyroid Activity

Following Intracerebral Injection of Morphine in the Rat .

Lu, K.H.: vide CHEN, C.L.

LUTTGE, W.G.: vide WHALEN, R.E.

MACLEOD, R.M.; FonTHAM, E.H., and LeHMEYER, J.E. (Charlottesville, Va.): Prolactin and Growth Hormone Production as Influenced by Catecholamines and Agents that Affect Brain Catecholamines ....

MARKS, B.H.: vide BHATTACHARYA, A.N.

MATSUMOTO, S.: vide HIRONO, M.

MEISAMI, E.; VALCANA, T., and TimiRAS, P.S. (Berkeley, Cal.): Effects of Neonatal

Hypothyroidism on the Development of Brain Excitability in the Rat

MEITES, J.: vide CHEN, C.L.

Moguilevsky, J.A.; Libertun, C, and FogliA, V.G. (Buenos Aires): Metabolic Sensitivity of Different Hypothalamic Areas to Luteinizing Hormone (LH), Follicle Stimulating Hormone (FSH), and Testosterone. 153

O'STEEN, W.K.: vide VAUGHAN, MARY K.

PECK, L.: vide SALCMAN, M.

PIECHOCKI, T.: vide KOSTOWSKI, $\mathrm{W}$.

PUIG, R.: vide LAWZEWITSCH, IRENE VON

QUINN, D.L.: vide EVERETT, J.W.

RAMIREZ, V.D.: vide ALVAREZ, E.O.

RAMIREZ, V.D.: vide BRUCE, J.O.

REDDING, T.W. and SCHALLY, A.V. (New Orleans, La.): A Study on the Mode

of Administration of Thyrotropin Releasing Hormone (TRH) in Mice. 329

REDMOND, W.C.: vide EVERETT, J.W.

REICHLIN, S.: vide ROWE, J.W.

REWERSKI, W.: vide KOSTOWSKI, W.

RICHERT, J.R.: vide ROWE, J.W.

Roos, J.: vide ARON, CL.

ROWE, J.W.; RICHERT, J.R.; KLEIN, D.C., and REICHLIN, S. (Rochester, N.Y.): Relation of the Pineal Gland and Environmental Lighting to Thyroid Function in the Rat 247

Salcman, M.; Peck, L. and EgDahl, R.H. (Boston, Mass.): Effect of Acute and Prolonged Electrical Stimulation of the Amygdala of the Dog upon Peripheral Plasma Concentrations of Corticosteroids 361

SAWYER, C.H.: vide KALRA, S.P.

SCHALLY, A.V.: vide BERTHOLD, K.

SCHALLY, A.V.: vide REDDING, T.W.

SHIMIZU, H.: vide DAIKOKU, $S$.

STARK, A.: vide FENDLER, $\mathrm{K}$.

STRASHIMIROV, D.: vide BOHUS, B.

SULMAN, F.G.: vide BEN-DAVID, M.

SULMAN, F.G.: vide DANON, A.

SWAAB, D.F. and JONGKIND, J.F. (Amsterdam): The Hypothalamic Neurosecretory Activity During the Oestrous Cycle, Pregnancy, Parturition, Lactation, and Persistent Oestrus, and After Gonadectomy, in the Rat............................................... 133

TALEISNIK, S. and Tomatis, M.E. (Cordoba, Argentina): Mechanisms that Deter mine the Changes in Pituitary MSH Activity During Pseudopregnancy Induced by Vaginal Stimulation in the Rat 368 
Index

TERASAWA, E.: vide KAWAKAMI, M.

TIMIRAS, P.S.: vide MEISAMI, E.

ToIVOLA, P. and GaLE, C.C, (Seattle, Wash.): Effect on Temperature of Biogenic

Amine Infusion into Hypothalamus of Baboon 210

TOMATIS, M.E.: vide TALEISNIK, S.

TRACZYK, W.Z.; GUZEK, J.W., and LESNIK, H. (Lodz): Distribution of Antidiuretic Substance in the Diencephalon and Mesencephalon of the Dog 56

VALCANA, T.: vide MEISAMI, E.

VAUGHAN, G.M.: vide VAUGHAN, MARY K.

VAughan, Mary K.; O’SteEN, W.K., and Vaughan, G.M. (Atlanta, Ga.): Estrous Cycle Changes after Prenatal and Neonatal Injections of Melatonin in Normal and Androgen-Sterilized Female Rats

VELASCO, M.E. vide KALRA, S.P.

VERMES, I.: vide FENDLER, K.

VOOGT, J.L.: vide CHEN, C.L.

WEYL SOKOL, HILDA (Hanover, N.H.): Evidence for Oxytocin Synthesis After Electrolytic Destruction of the Paraventricular Nucleus in Rats with Hereditary Hypothalamic Diabetes Insipidus

WHALEN, R.E. and LuTTGE, W.G. (Irvine, Cali.): Long-Term Retention of Tritiated

Estradiol in Brain and Peripheral Tissues of Male and Female Rats 90

WOLFSON, A.: vide ALEXANDER, B.

WURTMAN, R.J.: vide ANTON-TAY, F.

ZEILMAKER, G.H.: vide EVERETT, J.W.

Summaries of Articles: 1, 10, 19, 30, 49, 56, 65, 77, 90, 98, 109, 118,133,146, 153, 160, $168,175,180,194,197,210,220,228,236,247,255$, $265,274,283,295,301,311,319,329,336,343,349,361,368$

Subject Index

.............. 379

Varia 